\title{
RECENT TRENDS IN THE EDUCATION SYSTEM IN ETHIOPIA
}

\author{
Chala Wata Dereso ${ }^{1}$ \\ ${ }^{1}$ President, Bule Hora University, Ethiopia
}

\begin{abstract}
Ethiopia is the second-largest country in African content with a population of 905 million whereas Nigeria occupied first place with a population of 105 million. As per the Human Development Index, Ethiopia ranked as 173rd position out of 189 countries. It is one of the least developed countries (LDCs) in the world. Presently, Ethiopia has been facing various challenges an efficient education system and the rapid expansion of the population in Ethiopia. As per the African standards, by 2050 the population of Ethiopia will be raised to 191 million and less than 15 years of age people more than $40 \%$. Ethiopia is one of the faster-growing economies during the last decade about the fivefold raised i.e., from USD136 to USD 768. As per the World Bank, Ethiopia is one of the disadvantaged countries during the 20th century due to a lack of efficiency and shortage of teachers. This paper focuses on the recent trends in low-income country of Ethiopia primary, secondary, higher education, to investigate the expenditure incurred by the government influencing the growth of the economy and to give appropriate suggestions for the improvement of the education system in Ethiopia.
\end{abstract}

\section{Keywords}

Recent trends, primary education, secondary education, higher education, growth of education system.

Article Received: 10 August 2020, Revised: 25 October 2020, Accepted: 18 November 2020

\section{Introduction}

After the tenure of Derg in 1991, the education system in Ethiopia has been expanding in elementary, secondary, upper-secondary and higher education. For expanding education activities in Ethiopia some other problems were also started such as the shortage of funds and decline in the quality of education. The literacy rate in Ethiopia was 39\% in 2012. It is a very low comparatively least developed countries average of $77 \%$ in 2016. The quality of the education suffered a lot due to lack of funds, shortage of teaching staff, poor infrastructure, etc. By the end of 2015 , only $15 \%$ of university instructors were worked with the doctoral degree. Most of the university instructors are working with bachelor's degree qualifications. The research fund of Ethiopia was very low comparatively to other African countries. The private universities have expanded equal to public universities, the Former Prime Minister expressed that the private universities just printing diplomas and certificates and handover to the students due to that the quality of education decreasing.

\section{Review of Literature}

Many of the studies indicate that the education system in Ethiopia from the $19^{\text {th }}$ century to till- date. These are including Alcardo Alex Barakabitze, Anangisye William-Andy Lazaro, Neterindwa Ainea, Michael Hamza Mkwizu, Hellen Mazikum Alex Xavery Matofali, Aziza Iddi, and Camillius Sanga, (2019) highlights Information Communication Technology (ICT) models for analysing education transformational approach towards integrating ICTs in Africa's education system. Another study also represents in the same line system-based emphasis is required for improving the quality of education in Ethiopia Sisay Awgichew Wondemeteegh, (2016).

The government expenditure on pre-primary education is influencing the better results in their performance in the future expressed by Danlela Del Boca, Chlara Mondardini, Sarah Grace See, (2018). Albert-Enéas Gakusi, (2008) African education system has been facing serious challenges related to low and inequitable access to the education, learning outcomes and the capacity of education system is poor. It concludes a greater effort is required for providing quality education. Larger effects in the lower levels of education and technological changes will be influencing the expansion of education (Hannum and Buchmann, 2003). Sen, (1999) expressed that those countries are focusing on access to education and health is the benefit in the long-run, 
and eradication of poverty. Basic education leads to learning to do, to know, and to live together (UNSCO 2000; Torres 2004)

\section{The Problem of the study}

Even the government has been taking dynamic developmental activities for the effective education system in Ethiopia and allocation of huge funds for improving the quality of education, competence, development of the curriculum and contents in academic competence at the primary, secondary, and higher education level. Still, some problems have been facing in the Ethiopia education system. These are gender, inadequate inclusion of children, lack of quality of the education and competence, lack of curriculum development and contents in the academic subjects, lack of education facilities, etc. For achieving the target, still, it is the required expansion of enrolments in lower secondary education and increases the number of students to be admitted in secondary and higher education. Some of the countries are providing need-based, quota-based and preferential-based education (Mihyo, 2005). This study will focus on trends of the education system in Ethiopia and find the government expenditure on education for the effective education system and development of an economy.

\section{Research Questions}

1. What are the trends in primary, secondary and higher education in Ethiopia?

2. What are the trends expenditure incurred on education by the government for the development of an economy?

\section{The Objectives of the study}

1. To analyze the trends at primary, secondary and higher education in Ethiopia

2. To investigate the trends for allocation of funds by the government on education for the development of an economy

3. To give appropriate suggestions for policymaking and its implementation for the development of the education system in Ethiopia

\section{The Methodology of the Study}

This study mainly focused on secondary data from various research papers, documents related to Ethiopian history and data from Ministry of
Education. For analysing the data the researcher used a descriptive method to find out trends in primary, secondary, higher education in Ethiopia. Appropriate statistical tools such as correlation and regression analysis used for investigating the government expenditure on education for the sustainable development of an economy.

\section{Primary Education in Ethiopia}

Shifting of the education system from traditional to modern with the basic principle is the development of curriculum and modernizing Ethiopia. The curriculum was developed in French, Italian, Geez, Arabic and Amharic languages. The medium of the instructions was up to 1935 French only. In the mid-1950s the structure of primary education was 4 years. Later, it was changed to 6 years and its grading was also upgraded 1-8 which covered all the subjects. The primary education textbooks were obtained from other languages during this period. All school children had followed the Great Britain examination system. During 1955-72, 6-grade structures were influenced by America at primary school education. As per the new policy, the primary education was 6 years program; total of 8 years will be taken as general education, two year for general secondary education and two years for the training program. In 1989 elementary education was $29 \%$ and it rose to $86 \%$ by 2015 . The number of elementary schools was increased to 32,048 from 11,000; the students were enrolled from 3 million to 18 million during 1996-2014. The number of primary schools has increased to 33,373 from 12,089 net enrolment was also raised to $54 \%$ during 2002-2015, and drop-out was improved from $18 \%$ to $9 \%$ during 2009-14. The medium of instruction was taken as a mother tongue at the primary level.

Table: 01 the Trend of Gross Enrolment Ratio at Primary Level Education in Ethiopia during 2006-15

\begin{tabular}{|l|l|l|}
\hline Year & $\begin{array}{l}\text { Gross Enrolment } \\
\text { Ratio-\% }\end{array}$ & Growth-\% \\
\hline 2006 & 83.4 & 5.50 \\
\hline 2007 & 89.3 & 7.05 \\
\hline 2008 & 95.8 & 6.37 \\
\hline 2009 & 93.7 & -1.38 \\
\hline 2010 & 92.0 & -1.84 \\
\hline 2011 & 94.7 & 2.97 \\
\hline
\end{tabular}




\begin{tabular}{|l|l|l|}
\hline 2012 & 94.8 & 0.08 \\
\hline 2014 & 100.1 & 5.64 \\
\hline 2015 & 102.1 & 2.00 \\
\hline
\end{tabular}

(Sources: Ministry of Education)

The analysis represents the gross enrolment ratio at primary level education in Ethiopia during
2006-15. The GER has been increasing from 2006 to 2015 i.e., $83.4 \%$ in 2006 and it was raised to $102.1 \%$ in 2015 . The growth rate of GER has been decreasing to $2 \%$ from $5.50 \%$. The overall trend at primary level education was satisfactory during 206-2015.

\section{Figure: 01 Graphical presentations of The Trend of Gross Enrolment Ratio at Primary Level}

Education In Ethiopia during 2006-15

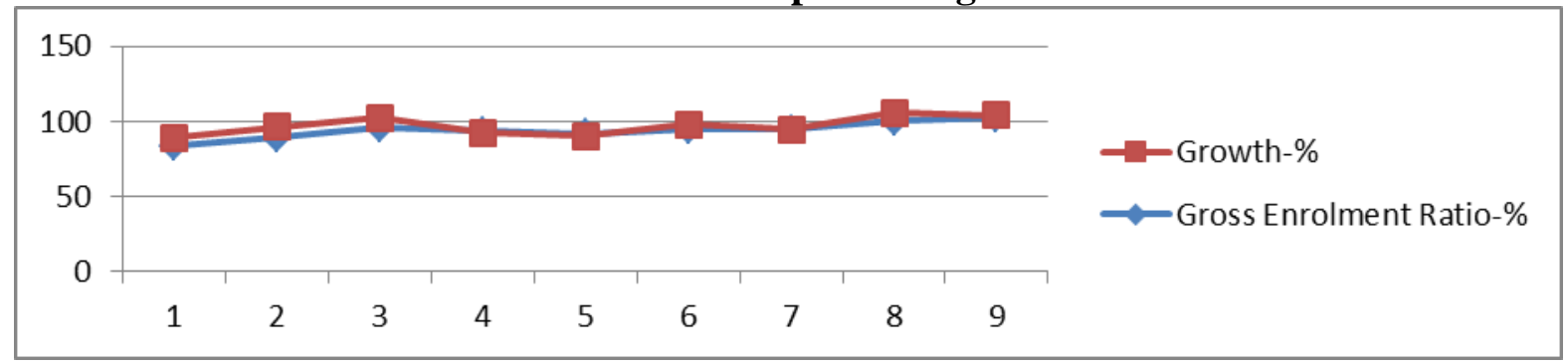

\section{Secondary Education in Ethiopia}

In $19^{\text {th }}$ century the trend of the secondary education system was to meet the needs of society, secondary schools, technical and vocational schools. There is advancement in the development of curriculum and publications. The structure of intermediate and secondary education was four years each (4-4). From 1947 onwards this was changed to 4 years. In the early period of the $20^{\text {th }}$ century, there were dynamic changes in the development of curriculum and universal education policy to eradicating illiteracy. As per the new education policy junior and, senior education was a 2-4 year program. Again it was changed two years for general secondary and the two-year training program. The number of schools was also increased from 369 to 424 during 19952002. Last 15 years i.e., 1999-2015 the growth rate was increased to $26 \%$ from $16 \%$. With the initiative of World Bank and USAID- the government was introduced Multimillion-dollar program during 2009-18 to improve the quality of general education and decentralization, revised curriculum procurement of learning materials and strengthening assessment. In this program involving 11 regions, 21 universities, and 36 colleges, 40000 schools had participated. Later, a program was initiated called Science, Engineering, and Mathematics (STEM) during 2015 for reinforcing education of Science \& Technology to secondary and preparatory schools. The performance of secondary education in Ethiopia was very poor (10\%) in comparison with lower-middle-income countries $(39.3 \%)$. The enrolment rates were drastically increased to $90 \%$ from $80 \%$ for secondary education and above $50 \%$ for upper secondary education by the end of 2018 . According to the Ministry of Education (MOE) enrolment of lower and upper secondary education in rural and urban areas has been decreasing during 2010-14, in rural areas, it was reduced from $85.79 \%$ to $78.85 \%$ and in urban areas decreased from $94.92 \%$ to $91.24 \%$. The Gross enrolment ratio in secondary education was $35.2 \%$ by the end of 2015 .

Table: 02 the Trend of Gross Enrolment Ratio at Secondary Level Education in Ethiopia during 2005-10

\begin{tabular}{|l|l|l|}
\hline Year & $\begin{array}{l}\text { Gross } \\
\text { Enrolment Ratio }\end{array}$ & Growth \\
\hline 2005 & 24.8 & -6.71 \\
\hline 2006 & 28.8 & 4.59 \\
\hline 2007 & 32.0 & 3.56 \\
\hline 2008 & 33.2 & 3.94 \\
\hline 2009 & 33.5 & 0.86 \\
\hline 2010 & 34.8 & 3.79 \\
\hline 2011 & 36.0 & 10.92 \\
\hline 2012 & 37.7 & 16.52 \\
\hline 2015 & 35.2 & 12.96 \\
\hline
\end{tabular}

(Sources: Ministry of Education)

The above analysis indicates that the Gross Enrolment Ratio at secondary level education in Ethiopia during 2005-2015. The GER ratio has been steadily increasing in Ethiopia. The Growth rate of GER at the secondary level was initially $6.71 \%$ in 2005 . Later, it was increasing up to $12.96 \%$ by the end of 2015 . The GER and its 
growth rate trend has been increasing from 2005-

2015.

Figure: 02 the Trend of Gross Enrolment Ratio at Secondary Level Education in Ethiopia during 2005-15

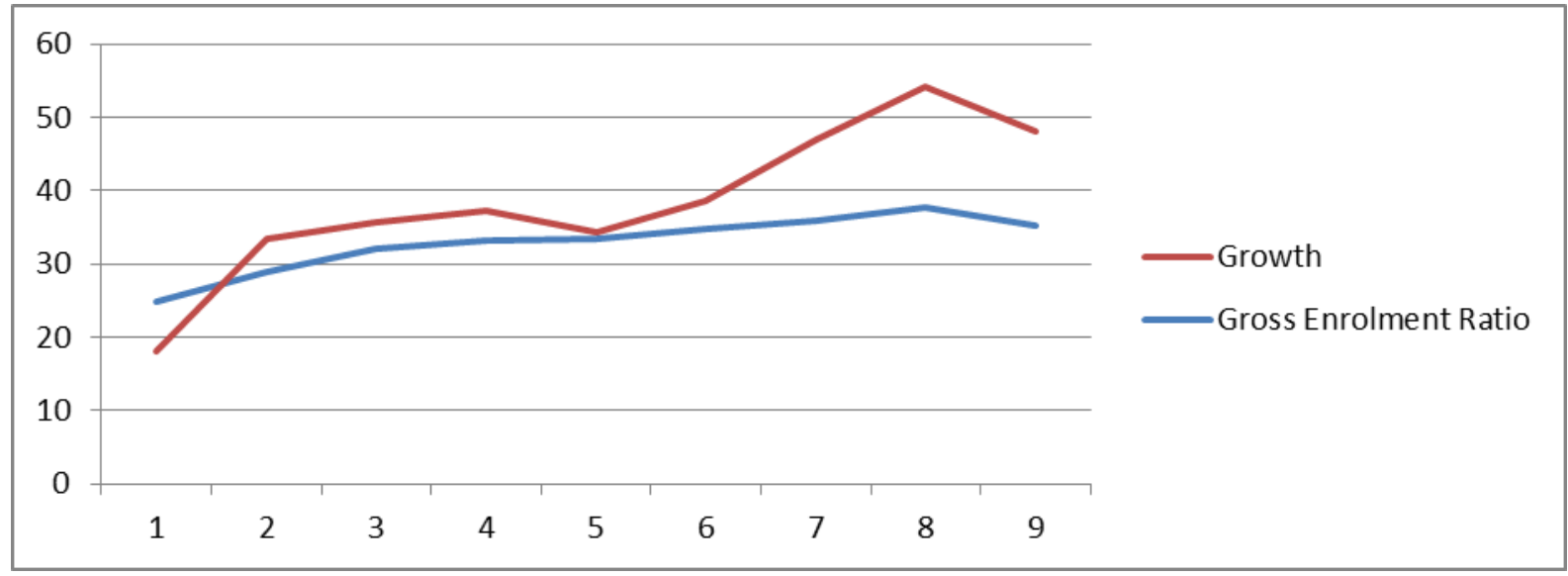

\section{Higher education in Ethiopia}

The government of Ethiopia has focused to promote the higher education as a sub-sector and with the objectives of quality and relevance, focusing on research and development. Comparatively, the sub-sector of higher education enrolment is very low in Ethiopia than in subSaharan countries. There are eight universities, thirteen colleges (teacher training colleges), polytechnic, mass media and water technology are three, and no. of private colleges. For degree courses to take four to five years, the Postgraduate program requires one to three years of study. All the higher education institutions are under the supervision of the Ministry of education. Each institute has its board of governors. The trend of higher education in Ethiopia was the establishment of new universities, amalgamating and elevating the status of other colleges and institutions. The total enrolment of students in higher education was increased from 42,132 to 87,431 during 19962001 whereas in the private sector enrolled students were 15,201 ; it is about $17.2 \%$ of total enrolment. The majority of the students are enrolled in diploma programs than post-graduate programs. The PG students are about $1 \%$.

Trends in Education expenditure by the government

The Ethiopian government is having a strong commitment to the development of education in Ethiopia. Effective education will be influencing other key sectors such as infrastructure and agriculture (OECD 2007). From time to time the government has to meet educational expenditure and assigning need-based additional teachers in three large regions- Amhara, Oromia, and the Southern Nations Nationalities and Peoples Region (SNNPR). More than 200000 additional teachers are required for achieving the pupilteacher ratio. To meet this requirement the government of Ethiopia has been increasing the education expenditure for the last one and halfdecade. The government allocation of expenditure was changed to general and higher education during 2003-08. The share allocated to higher education was reached $50 \%$, secondary education has been squeezed to less than $10 \%$. It was a very low comparison with India and Indonesia $30 \%$ by the end of 2009-10. Since 1994 the government of Ethiopia has been allocating education expenditure steadily increasing. By 2009, it was $23 \%$ of the total government expenditures and $5.3 \%$ of GDP.

Table: 3 the Trend of the Education Expenditure by the Government of Ethiopia and Its GDP during 1985-2010

(in Percentage)

\begin{tabular}{|l|l|l|}
\hline Year & $\begin{array}{l}\text { Total Government } \\
\text { Expenditure }\end{array}$ & GDP \\
\hline $1985-86$ & 8.2 & 2.4 \\
\hline $1990-91$ & 10.1 & 2.5 \\
\hline $1995-96$ & 15.7 & 3.8 \\
\hline $2000-01$ & 14.2 & 4.1 \\
\hline $2005-06$ & 20.7 & 4.6 \\
\hline $2009-10$ & 23.6 & 4.6 \\
\hline
\end{tabular}

(Source: World Bank 2005) 


\section{Figure:3 The Trend of the Education Expenditure By The Government Of Ethiopia And It's GDP In} Percentage during 1985-2010

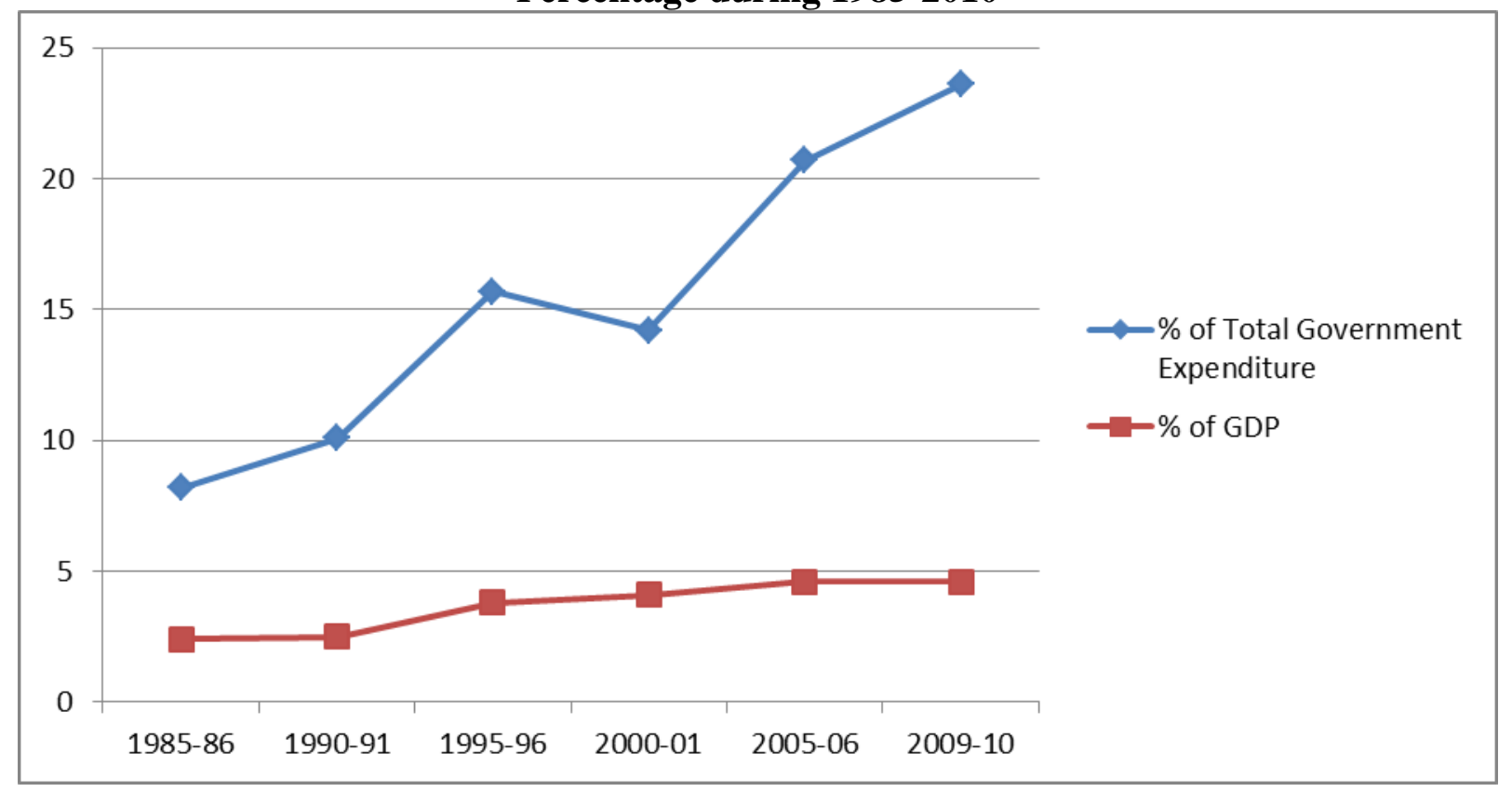

The analysis from the above table highlights government expenditure on education and \% of GDP has been increasing during 1985-2010. The government expenditure was triple time increased whereas GDP was doubled during the period. It is a positive indication when the allocation of more funds on education development, as a result of the GDP also increasing. This can be verified through a statistical tool.

\begin{tabular}{lc}
\multicolumn{3}{l}{ SUMMARY } & OUTPUT \\
\hline \multicolumn{2}{l}{ Regression Statistics } \\
\hline Multiple R & 0.930476 \\
R Square & 0.865786 \\
Adjusted R & \\
$\begin{array}{l}\text { Square } \\
\text { Standard }\end{array}$ & 0.832233 \\
Error & 2.435541 \\
$\begin{array}{l}\text { Observation } \\
\text { s }\end{array}$ & 6 \\
\hline
\end{tabular}

\begin{tabular}{llllll} 
ANOVA & & & & & \\
\hline & $d f$ & $S S$ & $M S$ & $F$ & $\begin{array}{l}\text { Significanc } \\
\text { e F }\end{array}$ \\
\hline \multirow{2}{*}{ Regression } & 1 & 153.060 & 153.060 & 25.8031 & \\
& & 9 & 9 & 9 & 0.007082 \\
Residual & 4 & 23.7274 & 5.93185 & & \\
& & 4 & 9 & & \\
Total & 5 & 176.788 & & & \\
\hline
\end{tabular}




\begin{tabular}{lllllllll}
\hline & Coefficient & Standar & & & & Upper & Lower & Upper \\
& $s$ & d Error & t Stat & P-value & Lower 95\% & $95 \%$ & $95.0 \%$ & $95.0 \%$ \\
\hline & & 4.14971 & & 0.29063 & & 6.47293 & & 6.47293 \\
Intercept & -5.04851 & 1 & -1.21659 & 5 & -16.57 & 6 & -16.57 & 6 \\
X Variable & & 1.09877 & 5.07968 & 0.00708 & & 8.63208 & 2.53073 & 8.63208 \\
1 & 5.581411 & 1 & 4 & 2 & 2.530733 & 9 & 3 & 9 \\
\hline
\end{tabular}

The above analysis refers to the relationship between the government expenditure on education (variable-1) and GDP (variable-2) has positively correlated during 1985-2010. The correlation between the variable was 0.930476 i.e., 93\% relationship between the variables. The government expenditure on education is taken as independent and GDP is the dependent variable. The analysis indicates that the government expenditure on education will be influencing towards GDP, the $\mathrm{R}^{\wedge} 2$ values 0.8657 i.e., above $87 \%$ and the significant value of a ' $p$ ' is 0.007 it is less than 0.05 . Hence, there is an impact on GDP by the government expenditure on education during 1985-2010.

\section{Findings of the Study}

Based on the above analysis it is observed that in the last twenty-five years the elementary education enrolled was accelerating the growth almost 3 times i.e., $30 \%$ to $90 \%$. The number of schools was also increased to three times i.e., 11,000 to 32,048 schools. The number of primary schools increased two and a half during 19902015. At the same time, the drop-out ratio has significantly reduced two times i.e., $18 \%$ to $9 \%$. The secondary education was also rapid improvement in GER during 2005-15. It was increased from $24.8 \%$ to $34.2 \%$ and the growth rate was drastically raised to $13 \%$ from $-6 \%$ during the period. The higher education enrolment in Ethiopia is very low than in sub-Saharan countries. The total enrolment of students was raised two times during 1996-2001. The majority of the students are enrolled in diploma courses than P.G. The total PG students are $1 \%$ in Ethiopia. The government expenditure on education in Ethiopia was improved three times during 1985-2010. As a result, the GDP was also increased to 4.6 times from 2.4 times. The relationship between GDP and government expenditure on education was positive. Hence, the impact of expenditure on education by the government is positive on the development of an economy.

\section{Suggestions of the study}

It may be suggested that the government should be focused on the expansion of education in rural areas, development of curriculum and contents, increasing enrolments in secondary and higher education is very important for an effective education system in Ethiopia. It is also suggested that the government will concentrate allocation of funds on research and development in thrust areas for encouraging the universities, private colleges, and students for inclusive development of an economy.

\section{Conclusion}

It may conclude that the trends in the Ethiopian education system have been significantly upward movement at primary, secondary and higher education. The effective functioning of human capital will be turn out to be important for an economic success (Barro 1991, Becker 1995, Barro and Lee 2000; Lucas Jr; 2003; Hanushek and Wößmann. 2007). Ethiopia is one of the fast-growing populations, to meet their fundamental needs and requirements the government has to focus on making and implementing new education policies for the sustainable development of an economy. This study will be helpful to the policymakers to understand the trends in Ethiopia's education system and they will take necessary policy decisions for the effective education system and its development of an economy.

\section{References}

[1] Alcardo Alex Barakabitze, 1. A.-A. (2019). Transforming African Education Systems in Science, Technology, Education Research International, 1-30.

[2] Barro, R. J. (1991). "Economic Growth in a Cross-section of Countries",. Quarterly Journal of Economics, 106.

[3] Daniela Del Boca, C. M. (2018). Government Education Expenditures,. IZA - Institute of Labor Economics: IZA Institute of Labor Economics. 
[4] Gakusi, A.-E. (2008). Third Annual African Economic Conference on "Globalization,. African Development Bank.

[5] Hannum, E. a. (2003). The Consequences of Global Education. Cambridge: Cambridge, MA: American Academy of Arts.

[6] OECD. (2007). Understanding the Social Outcomes of Learning. Paris: Centre for Education Research and Innovation.

[7] P.B., M. (2005). Education in Africa: Innovations and Challenges, The Commonwealth Heads of Government Meeting,, 25-28.

[8] Sen, A. (1999). Development as Freedom. New York: Alfred Knopf Inc.

[9] UNESCO. (2000). The Dakar Framework for Action "Education for ALL: Meeting Ours. UNESCO: World Education Forum, Dakar Senegal. Paris:.

[10] Wondemetegegn, S. A. (2016). The Historic Move, Contemporary Challenges and Opportunities. International Journal of African and Asian Studies, 56-66. 